\title{
Involving Elderly and Disabled Tourists as Active Participants in Energy Savings
}

\author{
Mireia Ferri Sanz, Estrella Durá Ferrandis, Jorge Garcés Ferrer \\ Polibienestar Research Institute
}

\begin{abstract}
This paper presents some recommendations about the inclusion of accessibility criteria in the design of tourism resources in order to involve elderly and disabled people in their energy and waste saving policies. With these criteria, tourism entities contribute to the development of sustainable tourism, and consequently, to build environmentally-friendly tourism infrastructures and services.
\end{abstract}

\section{Introduction}

Tourism is a European relevant sector in terms of economic and employment potential because Europe is a major tourist destination and six of the EU Member States are in the world's top 10 destinations for holidaying. This prevailing situation has important environmental implications [1].

In this sense, the environment suffers relevant changes as result of tourism adaptation. For instance, forests have been reduced to build ski rinks that cause damages in erosion and floods; the beach spaces have become bigger with the consequently reduction of virgin environments for fauna and flora; etc. Moreover, the tourism sector and tourists' journeys contribute to the climate change emitting around the $5 \%$ of carbon dioxide emission worldwide. The tourists' journeys, to and inside the destinations, represent the $75 \%$ of all carbon dioxide emissions of the tourism sector. Additionally, the previsions establish that the carbon dioxide emissions will augment $130 \%$ in 2035 under a normal scenario [2]. From other part, tourism contributes to increased water consumption and litter production [3]. In this field, tourists are often responsible of contributing to the environmental damage. As consequence, tourist behavior remains as a crucial factor for sustainability [3].

In this framework, the European Commission adopted in 2006 the Communication entitled 'A renewed EU tourism policy: towards a stronger partnership for European tourism'. This document addressed a range of challenges that European tourism is facing that require a policy response at EU level. These challenges are: Europe's ageing population, growing external competition, consumer demand for more specialized tourism and the need to develop more sustainable and environmentally-friendly tourism practices [4].

In this sense, within the definition of sustainable and environmentally-friendly tourism infrastructures and services, the integral management of energy and waste materials is considered with the objective to investigate new technologies that respond to the tourism huge energy needs. It consists in to achieve a sustainable tourism development along the whole tourism supply chain which considers all the tourism resources that could interact with tourists from the beginning of the trip until the end. With this purpose, the sustainable tourism model Garcés-Ferri [5], presented in the Figure 1, states that the development of a sustainable tourism is achieved through Social Tourism Policy that uses Accessible Social Tourism as a tool. The Accessible Social Tourism integrates social tourism and accessible tourism and has the following impacts: economic and social benefits, friendly environments, and efficiency in health and social systems.

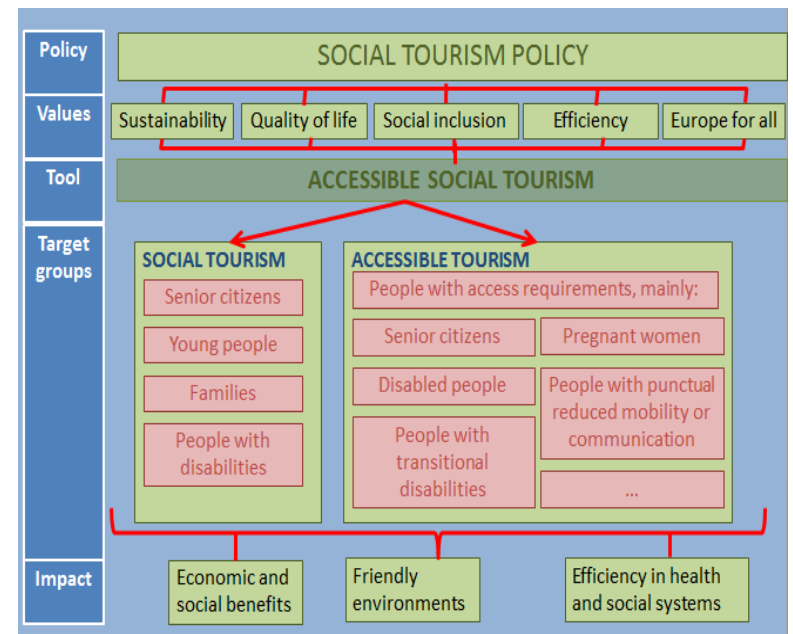

Figure 1. Sustainable tourism model Garcés-Ferri; Source: developed by the authors [5]

At this stage it is important to mention what means Social Tourism Policy and Accessible Social Tourism. Social Tourism Policy is the policy that has the objective to increase the quality of life and wellbeing of citizens making tourism accessible to persons with special needs, generating health and social benefits for their users and consequently impacts in the efficiency of social and health systems and the economy of destinations. Accessible Social 
Tourism is defined as a tool addressed to involve people with special needs (mainly financial and accessibility needs) as active participants in tourism, at the same time promoting social benefits ${ }^{1}$ for their users and economic benefits for society and markets [6].

Following the sustainable tourism model GarcésFerri and looking for a social sustainable and energy efficient tourism, it is essential to integrate the variable accessibility within the tourism supply chain for the following reasons:

The no consideration of accessibility in the tourism infrastructures and services design implies to leave an important market share unattended. Europe is living an ageing process that represents a long term trend [7] and produce that older people will represent the $30 \%$ of European population in 2060 [8]. Moreover, the ageing process and the major prevalence of chronic diseases cause that dependent and disabled people will also augment in the following decades.

The consideration of accessibility in the tourism resources design allows to all the guests to contribute in the energy and waste saving in an active way.

The accessibility consideration reflects the quality of tourism resources. Thus, the accessible environments in tourism sector give tourism entities an important image and competitive benefit [9].

As consequence, tourism entities should include the accessibility variable in their infrastructures and services if they want to maintain themselves in the market and contribute to developing a sustainable and environmentally-friendly tourism. With the accessibility consideration they could involve all their guests in their energy and waste saving policies. In this context, the new technologies and the design of age-friendly and disability-friendly environments have a relevant role. Thus, destinations need to adopt ICT solutions and become technology experts, ecoefficient and environmentally innovative in their operation. In fact, there are knowledge and understanding of mechanisms for sustainable tourism development applying ICT [10]. From other part, the design of age-friendly and disabled-friendly environments is a necessary and logical response to promote the wellbeing of citizens and keep cities thriving [11].

In order to involve all the tourists in the energy and waste saving policies, the Polibienestar Research Institute at University of Valencia (Spain) was

\footnotetext{
1 The authors meant by social benefits the positive effects related with tourism by the bibliography, such as: wellbeing, self-perceived health, mental health and inclusion.
}

contracted in the framework of the project THOFU (Technologies for the hotel of the future) funded by the Spanish Centre for Industrial Technological Development. This project tries to promote the hotel supply through joint research on a new concept of the hotel of the future, from the spaces and construction to objects and the interaction with guests and Internet. The tasks of Polibienestar are focused to make contributions to the definition of the reference model of spaces and objects design. Concretely, Polibienestar has analyzed the design of environments that helps to reduce the energetic consume with the basis of usable and accessible criteria. This paper presents some recommendations made by Polibienestar in order to involve elderly and disabled guests in the hotel energy and waste saving policies.

\section{Methodology}

The definition of the reference model of the future hotel involves the whole hotel lifecycle, which means, from the selection of materials to their potential demolition. In this framework, our purpose is to detail the accessibility criteria addressed to energy and waste savings that allow people with special needs to be active participants of these savings. In order to provide these criteria, authors have developed qualitative methodology through a deep documental review about accessibility, universal design, disabled people, elderly, architectural barriers, energy savings, ICT and other related issues available in studies, laws, European normative, publications and standards.

Moreover, authors have used the results of the project "Research for the improvement of knowledge in accessible social tourism for all in Spain Socialtourism" funded by the Spanish Ministry of Economy and Competitiveness (ref.: CS0201015425). Within this project, researchers from Polibienestar have developed the Self-Assessment Model of Accessible Social Tourism - SAMAST that is online available in the SOCIALTOURISM platform ${ }^{2}$. Using this platform, private and public tourism managers can self-asses the accessibility of their tourism infrastructures and services, know the elements that they should change in order to became accessible and the correct way to change these elements on the basis of universal design and considering different kinds of disability (hearingspeaking, visual, physical and mental). For the establishment of the model, Polibienestar has defined universal accessibility criteria. Sometimes, these criteria define some requirements compliance and sometimes they establish some specific measures [6].

\footnotetext{
${ }^{2}$ www.socialtourismplatform.com
} 
The SAMAST considers the whole tourism supply chain: accommodation, leisure and healthy spaces, parking places, environment, activities, transport, and restaurants and cafes. From the SAMAST, authors have selected the aspects related with energy and waste savings in the hotel field.

\section{Results}

The results of the research carried by the authors offer some recommendation about the needs of elderly and disabled people to be considered in the design of sustainable hotels, in terms of energy and waste savings. These recommendations could be extrapolated to other tourism infrastructures or to general buildings because they are based on universal criteria.

Concretely, in this paper the authors offer some keys to the inclusion of elderly and disabled people in energy and waste saving policy in hotel infrastructures. In this sense, authors identify the following different spheres:

\subsection{Heating}

Besides the standard criteria to keep the warm inside the buildings and not to waste it; tourism managers should consider other aspects in order to involve elderly and disabled people in the heating saving. In this sense, the heating controllers should be installed at a height that allows people with wheelchairs to switch them on / off and to change the temperature. These controllers should have an easyto-use and friendly design to allow all guests to understand how to use them. Moreover, as elderly people are one of the main vulnerable groups to heat, the tourism infrastructures should be programmed to keep the temperature at 20 degrees as minimum [12]. Likewise, doors and windows should respond to accessibility criteria that allow people with reduced mobility to open and close them to keep the warm inside their room. In this sense:

- The doors should have a different and contrasted color [13]; the doorknobs should be on both door sides at $0.90 \mathrm{~m}$ of height with an ergonomic design [13] and contrasted color. Also, it is recommended that doors have a horizontal rod at the same height of the doorknobs to facilitate their use [14].

- The windows should not be more than $1 \mathrm{~m}$ height and they should have an easy open system [15].

\subsection{Water saving}

The incorporation of water saving devices in taps should not avoid their ergonomic and one-hand use design. The accessible design of taps make possible that all guests could use them in an easy way and, consequently, contribute to the water saving. It is recommended to install showers instead of baths because both their accessibility and water saving implications. In addition, the volume of flow control installed in showers should consider people that take the shower sitting in a chair. From other part, if the hotel wants to involve elderly and people with visual impairments in the water saving with the reuse of towels during their stay, the informative panels should respond to the accessibility criteria described below for the paper savings.

\subsection{Light saving}

The presence of detectors for switch on and off the lights in the different rooms of the hotel should detect person in wheelchairs and people walking at different speeds. For detecting people in wheelchairs, the detectors should consider the standard dimensions of a wheelchair: $0.94 \mathrm{~m}$ high, $0.6 \mathrm{~m}$ wheels, $1.20 \mathrm{~m}$ long and $0.7 \mathrm{~m}$ wide [13]. Also, the switches should be installed at a height that allows people with wheelchairs to switch them on and off (between $0.80 \mathrm{~m}$ and $120 \mathrm{~cm} \mathrm{[16])} \mathrm{and} \mathrm{they} \mathrm{should} \mathrm{be} \mathrm{contrasted}$ color. In the same line, if the room has a target switch, it should be also at a suitable height and contrasted from the wall. Finally, the curtains and blinds should have an easy mechanism to open and close in order to allow all guests independently of their limitations to use the solar light.

Independently of the light saving systems, it is recommended to install pilot light along overnight in halls and rooms to facilitate the direction of elderly people. Moreover, the light intensity should be suitable in the different rooms of the hotel to guarantee the security of all guests. Considering the more beneficial criteria established by the literature and normative, the light intensity should be, depending on the place, at least the following:

- Stairs, fixed ramps and escalators: 150 lux for inside spaces [17] and 30 lux for outsides rooms [18].

- Level crossings: 100 lux [17].

- Elevators: 300lux [26].

- Itinerary: average of 200 lux for inside spaces [17] and 20 lux for outside [19].

- Car park: 50 lux for inside car parks and 100 lux for outside car parks [19]. 


\subsection{Paper saving}

The policy of paper saving in the hotel should not produce a lack of information. Relevant information, like fees, evacuation plan, restaurant menu, etc., should be available in Braille and in printed paper with the following specifications [20] in order to respond to the needs of elderly people and people with visual impairments:

- Simple letter (like Arial or Verdana without bold type) numeric characters and photos or images.

- $\quad$ Letter size between 12 and 14 points.

- Capital letters only for short words, titles, signs, etc.

- Space between letters of a quarter of the height of the letter.

- Space between lines of 25-30\% approximately of the size of the letter.

- $\quad$ Line length between 70-90 characters.

- Space between columns marked clearly and without images between them.

- Paragraphs short and concise.

- White or yellow paper and black letters.

- Paper with a matt finish.

- The thickness of the paper should prevent that the printing of one page interfere reading the words on the other.

- $\quad$ Avoid the use of draws as background.

- Images should not be inserted between the texts.

- $\quad$ Text written in horizontal and left aligned.

\subsection{Waste saving}

With the objective to achieve that all the hotel guests collaborate in recycling, it is recommended that all recycling bins have a Braille description about the kind of waste to introduce and a simple graphic illustration. Likewise, if the hotel develops activities to protect the environment and wants to share them with its clients through informative panels, these panels should be accessible for all users. For that purpose, the panels may offer the information in Braille, a suitable letter size and font, characters contrasted with the background, etc. (as mentioned previously for paper saving).

Finally, the recyclable products and wrappers bought by the hotel should consider its usability. That means, wrappers should be open in an easy way, the information provided should be legible, the plastic/carton cups put in the rooms of disabled or elderly people should respond to ergonomic design, etc.

\section{Conclusions}

European tourism is a relevant sector that should respond to their environmental implications. Moreover, it is facing new challenges that require a respond from tourism entities and policy at EU level like Europe's ageing population [4]. In this framework, the model Garcés-Ferri [6] states that the promotion of sustainable tourism implies that public and private tourism entities should integrate the accessibility criteria through the development of Social Tourism Policies that use Accessible Social Tourism as a tool. With this model, tourism entities could achieve the following impacts: economic and social benefits, friendly environments, and efficiency in health and social systems. Moreover, tourist behavior remains a crucial factor for tourism sustainability [3]. The achievement of these impacts through the model Garcés-Ferri [6] and the active role of tourists have guided this research.

Concretely, this paper is focused in the accessibility related to energy and waste savings in hotels. In this sense, considering accessibility, hotels could involve elderly and disabled people in their energy and waste saving policies as active participants. This consideration represents more relevance because the demographic and epidemiological changes that Europe is currently living that cause that elderly and disable people will augment in the following decades [15-17]. In this line, this paper has presented some recommendations to involve elderly and disabled people in these policies in different spheres of the hotel (heating, water, light, paper and waste savings). These recommendations are basic criteria that do not require huge investments but contribute to the active participation of elderly and disabled people in energy and waste saving policies, such as design of taps, height of the light switches and braille description in recycling bins.

Moreover, these criteria could be extrapolated to other tourism infrastructures in order to involve tourists in energy and waste savings along the whole tourism supply chain (restaurants, cafes, leisure spaces, etc.) and not only in hotels or other accommodations. Furthermore, these criteria are based on universal criteria so they are not exclusive designed for tourism sector, so entities from other sectors could apply them in order to achieve a sustainable environment.

\section{References}

[1] Eurostat, "Tourism introduced", Statistic Explained, 2013,

http://epp.eurostat.ec.europa.eu/statistics_explained/ind ex.php/Tourism_introduced (12 March 2013). 
[2] World Tourism Organisation (2009) "From Davos to Copenhagen and Beyond: Advancing Tourism's Response to Climate Change".

[3] European Environment Agency and Office for Officia Publications of the European Communities (2007) "Sectors that drive environmental change", chapter 7 of the "Europe's environment - The fourth assessment".

[4] Commission of the European Communities, "Communication from the commission: A renewed EU Tourism Policy: Towards a stronger partnership for European Tourism”, COM (2006). Brussels, 134 final.

[5] Garcés, J. and Ferri, M. (unpublished) "Sustainable tourism model Garcés-Ferri".

[6] Garcés, J. and Ferri, M. (2012) "Research for the improvement of knowledge in social tourism for all in Spain (Socialtourism)", project funded by the Spanish Ministry of Economy and Competitiviness (ref.: CS0201015425).

[7] Eurostat (2010) "Population structure and ageing. Statistics Explained. European Commission"; http://epp.eurostat.ec.europa.eu/statistics_explained/ind ex.php/Population_structure_and_ageing (18 August 2012).

[8] Eurostat (2011) "Population projections. Statistics explained";

http://epp.eurostat.ec.europa.eu/statistics_explained/ind ex.php/Population_projections (18 August 2012).

[9] Stamm, C.; McCabe, S. and Folch, A. (2011) "Supply side perspectives on social tourism", paper presented in the $9^{\text {th }}$ Annual ESPAnet Conference 2011, stream 17: Tourism, leisure time and social welfare.

[10] Ali, A. and Frew, A.J. "ICT and its role in sustainable tourism Development"; http://qmu.academia.edu/AndrewFrew/Papers/115822/ ICT_and_its_Role_in_Sustainable_Tourism_Develop ment (18 August 2012)

[11] World Health Organisation (2007) "Global agefriendly cities: a guide", France.

[12] Spanish Ministry of Health and Consumption (2011) "Plan Nacional de Actuaciones Preventivas de los efectos del exceso de temperaturas sobre la salud", Madrid.

[13] Rovira-Beleta, E. and Folch, A. (2010) "Accessibility guide for companies", Madrid: club de Excelencia en Sostenibilidad.

[14] Innovaciones Sociosanitarias, "Nuevas tecnologías para incrementar la competitividad de las empresas hacia un nuevo consumidor turístico: el turismo de personas con discapacidad", funded by the Spanish Misnistry of Industry, Tourism and Commerce and the Ministry of Science and Innovation.

[15] Predif, Fundación ACS and la Caixa (2007) "Cómo hacer hoteles accesibles para personas con movilidad reducida", Madrid.

[16] Ministerio de Vivienda, "Royal Decree 173/2010, of 19 February, amending the Technical Building Code, approved by Royal Decree 314/2006, of 17 March, on accessibility and non-discrimination of people with disabilities", ["Real Decreto 173/2010, de 19 de febrero, por el que se modifica el Código Técnico de la Edificación, aprobado por el Real Decreto 314/2006, de 17 de marzo, en materia de accesibilidad y no discriminación de las personas con discapacidad"]

[17] Ministerio de la Presidencia, Royal Decree 1544/2007 of 23 November, regulating the basic conditions of accessibility and non-discrimination for access and use of transport modes for people with disabilities ["Real Decreto 1544/2007, de 23 de noviembre, por el que se regulan las condiciones básicas de accesibilidad y no discriminación para el acceso y utilización de los modos de transporte para personas con discapacidad"]

[18] Barreras Arquitectónicas, "Guía de accesibilidad. Edificación. Medios de elevación"; http://www.mldm.es/BA/23.shtml (18 August 2012)

[19] Ministerio de Vivienda, "VIV/561/2010 Order of February 1, which develops technical document of basic conditions of accessibility and nondiscrimination for access and use of developed public spaces.", ["Orden VIV/561/2010, de 1 de febrero, por la que se desarrolla el documento técnico de condiciones básicas de accesibilidad y no discriminación para el acceso y utilización de los espacios públicos urbanizados"]

[20] ONCE, "Recommendations to present printed text accessible to people with visual impairments", ["Recomendaciones para presentar textos impresos accesibles a personas con deficiencia visual"]

\section{Acknowledgements}

Polibienestar Research Institute thanks the Spanish Centre for Industrial Technological Development and the Spanish Ministry of Science and Innovation for their support in this project (ref.: CEN-20101019). Furthermore, many thanks to Sacyr Vallehermoso for relying on Polibienestar to develop the research work. 